\title{
Improving Student Citizenship Education Learning Outcomes through Cooperative Learning Types of Group Investigations in Class X.3 State Senior High School Makassar
}

\author{
Musdalifah Syahrir \\ Pancasila and Citizenship Education Study Program, Teacher Training and Education Faculty, \\ Muhammadiyah University of Makassar, Jl. Sultan Alauddin No.259, Makassar, Indonesia \\ Corresponding Author: Musdalifah Syahrir Email: musdalifahsyahrir@unismuh.ac.id
}

History: Received 08/12/2021 | Revised 10/22021 | Accepted 25/12/2021 | Published 31/01/2022

\begin{abstract}
This research is a class action research (classroom action research) which aims to improve student-learning outcomes in class X.3 State Senior High School Makassar through a cooperative learning type investigation group (Group Investigation). The subjects of this study amounted to 39 people, consisting of 14 males and 25 females. This research was conducted in two cycles. From cycle I to cycle II, the cooperative learning model of group investigation type (Group Investigation) is used by continuously improving the quality of group learning implementation. As for the results of the research conducted over two cycles, it can be concluded that: 1) Group investigation type cooperative learning (Group Investigation) can improve student learning outcomes in Class X.3 State Senior High School Makassar in Civics Learning, 2) Student learning outcomes increase based on the achievement of scores which has exceeded the criteria of success with a very good category. The achievement is that the deficiencies in the first cycle can be overcome so that there is an increase in student activity which is indicated by an increase in student learning outcomes in the high category. The conclusion that can be drawn from the results of this study is that the application of the group investigation type learning model (Group Investigation) can improve student learning outcomes in Civics subjects in class X.3 State Senior High School Makassar.
\end{abstract}

Keywords: Learning Outcomes, Cooperative Learning Types of Group Investigation.

\begin{abstract}
Abstrak. Penelitian ini adalah penelitian tindakan kelas (classroom action research) yang bertujuan untuk meningkatkan hasil belajar siswa kelas X.3 SMAN 10 Makassar melalui pembelajaran kooperatif tipe investigasi kelompok (Group Investigation). Subjek penelitian ini berjumlah 39 orang, terdiri dari 14 orang laki-laki dan 25 orang perempuan. Penelitian ini dilaksanakan dalam dua siklus. Dari siklus I ke siklus II menggunakan model pembelajaran kooperatif tipe investigasi kelompok (Group Investigation) dengan senantiasa meningkatkan kualitas pelaksanaan belajar kelompok. Adapaun hasil penelitian yang dilaksanakan selama dua siklus dapat disimpulkan bahwa : 1) Pembelajaran kooperatif tipe investigasi kelompok (Group Investigation) dapat meningkatkan hasil belajar siswa Kelas X.3 SMA Negeri 10 Makassar dalam Pembelajaran PKn, 2) Hasil belajar siswa meningkat didasarkan pada pencapaian skor yang telah melampaui kriteria keberhasilan dengan kategori sangat baik. Adapun pencapaiannya yaitu kekurangan yang terdapat pada siklus I sudah dapat diatasi sehingga terjadi peningkatan keaktifan siswa yang ditunjukkan dengan peningkatan hasil belajar siswa yang berada pada kategori tinggi. Kesimpulan yang dapat ditarik dari hasil penelitian ini adalah penerapan model pembelajaran tipe investigasi kelompok (Group Investigation) dapat meningkatkan hasil belajar siswa pada mata pelajaran PKn kelas X.3 SMA Negeri 10 Makassar.
\end{abstract}

Kata kunci: Hasil Belajar, Pembelajaran Kooperatif Tipe Investigasi Kelompok. 


\section{INTRODUCTION}

Based on Law no. 20 of 2003 concerning the National Education System states that "Education is a conscious and planned effort to create a learning atmosphere and learning process so that students actively develop their potential to have religious spiritual strength, self-control, personality, intelligence, noble character, and skills that needed by himself, the community, the nation and the State".

According to the law, several things are very important for us to criticize from the concept of education. First, education is a conscious, planned effort, this means that the educational process in schools is not a process that is carried out carelessly and haphazardly. Still, a process that aims so that everything teachers and students do is directed at achieving goals.

Second, the planned educational process aims to create an atmosphere of learning and the learning process. This means that education should not override the learning process. Education is not merely trying to achieve learning outcomes but how to obtain results or learning processes in children. Thus, in education, the process and learning outcomes must be balanced. Education that only emphasizes one of them will not form a fully developed human being.

Third, the learning and learning atmosphere is directed to develop their potential. This means that the educational process must be student-oriented (active student learning). Education is an effort to create the possibility of students. Thus, children must be seen as developing organisms and have potential. The task of education is to develop students' potential, not to cram subject matter or force children to memorize data and facts.

Fourth, the end of the educational process is the ability of children to have religious, spiritual strength, self-control, personality, intelligence, noble character, and skills needed by themselves, society, nation, and state. This means that the educational process leads to children's skills according to their needs. These three aspects (attitude, intelligence, and abilities) are the direction and goals of education that must be pursued (Cahyani et al., 2019).

The problem of education that always arises is the imbalance between what can be achieved by education and the objective demands of society. Society always demands more effective educational operations. This demand is a challenge for us, the educators, to change the way of thinking and working that is no longer appropriate. Environmental change demands a change in the approach, and we must also make changes in the management and implementation of education. (Joseph, n.d.)

Citizenship Education is a subject that focuses on the formation of a diverse self in terms of religion, socio-cultural, language, 
age, and ethnicity to become intelligent, skilled, and characterized citizens as mandated by Pancasila and the 1945 Constitution (Akbal, 2016).

One of the problems facing our world of education is that the learning process is still weak. In the learning process, children are less encouraged to develop thinking skills. The learning process in the classroom is directed at the child's ability to memorize information; The child's brain is forced to remember and store various information without being required to understand the information it reflects on, relating it to everyday life.

It is still far from what we expect regarding the quality of education, especially education at the high school level. Therefore, the authors feel very interested and need to conduct further research to know more about efforts to improve student learning outcomes in Civics learning through cooperative learning of group investigation type (group investigation) at State Senior High School 10 Makassar.

Seeing the low condition of student learning outcomes, several efforts were made, one of which was giving assignments to students. Providing group assignments using a group investigation type learning model (group investigation) to students is expected to improve their learning outcomes so that repetition and reinforcement of the material given at school are expected to increase students' learning outcomes.
Based on the problems obtained through observations of teachers and students of class X.3 State Senior High School Makassar., it was revealed that what causes low learning outcomes and student achievement in Civics subjects is that teachers only tend to use the lecture method, so students do not have the opportunity to study in groups. Besides that, the teacher also does not involve students actively in the learning environment and uses fewer learning models. The teacher dominates the lecture method without allowing students to do group learning using the learning model so that students are less motivated in the learning process. To solve the problem above, studying using a learning model, namely the cooperative learning model of group investigation type as an alternative action in improving Civics learning outcomes through collaborative learning of group investigation type in class X.3 State Senior High School Makassar..

The selection of the group investigation type learning model prioritizes students' creativity, and students choose topics to investigate and conduct in-depth investigations on the selected issues. Next, prepare a report and present the message to the whole class to increase student learning outcomes more effectively and efficiently. The model is suitable to be applied to Civics subjects. (Tien, Woro, 2018). Therefore, the researcher intends to address this problem in classroom action research (CAR). 
For this reason, starting from these educational problems, the author raised CAR's title, "Improving Student Citizenship Education Learning Outcomes Through Cooperative Learning Types of Group Investigations in Class X.3 State Senior High School Makassar".

\section{RESEARCH METHODS}

In this Classroom Action Research, the research subjects were students of class X.3 State Senior High School Makassar with 39 students consisting of 14 male students and 25 female students. This research was conducted at State Senior High School Makassar, located at Jalan Tamangapa Raya V No. 12. Right in class X.3.

An action plan was a process of compiling actions developed in the learning process. This plan was structured flexibly to anticipate various impacts in the field so that research was carried out effectively. This planning activity begun with reviewing the lesson plans for high school teachers for class X.3 for the appropriateness of time between subject matter and research plans, making observation sheets to observe learning conditions in class when the action takes place, preparing lesson plans, Student Worksheets (LKS), and other instruments. (Hamdani, 2010).

Before carrying out the action, it is necessary to take preparatory action. Activities at this stage are: a. Preparation of lesson plans with the learning model planned in the CAR based on consultation with the teacher.

b. Preparation of problem sheets/student worksheets following the learning indicators based on consultation with the teacher.

c. Make test questions held to determine student learning outcomes based on consultation with the teacher.

d. Form a heterogeneous group both in terms of academic ability and gender.

e. Explain to students regarding the implementation technique of the cooperative learning model of the group investigation type that will be carried out. (Ulfi Yulismina, Warsiti, 2012)

Action implementation is the stage of implementing an action plan compiled collaboratively between researchers and classroom teachers to improve learning activities that have not been as expected. (Haryati, 2020).

Evaluation is done utilizing observation by researchers to find out how the learning activities take place.

The last step is to reflect (reflection) on the results that have been achieved in each cycle. If the results achieved in the first (first) cycle do not match the indicators and targets (80\%) according to the plan, it will be discussed with the teacher with alternative solutions, and then the next action is planned. 
This classroom action research is planned in two cycles, in which the first cycle is carried out in two (2) meetings and the second cycle is carried out in two (2) meetings, but if the second cycle is not successful, the next cycle will continue. Each cycle consists of planning, implementation, observation, and reflection stages. (Ratnaya, 2013). This is as illustrated in the following chart:

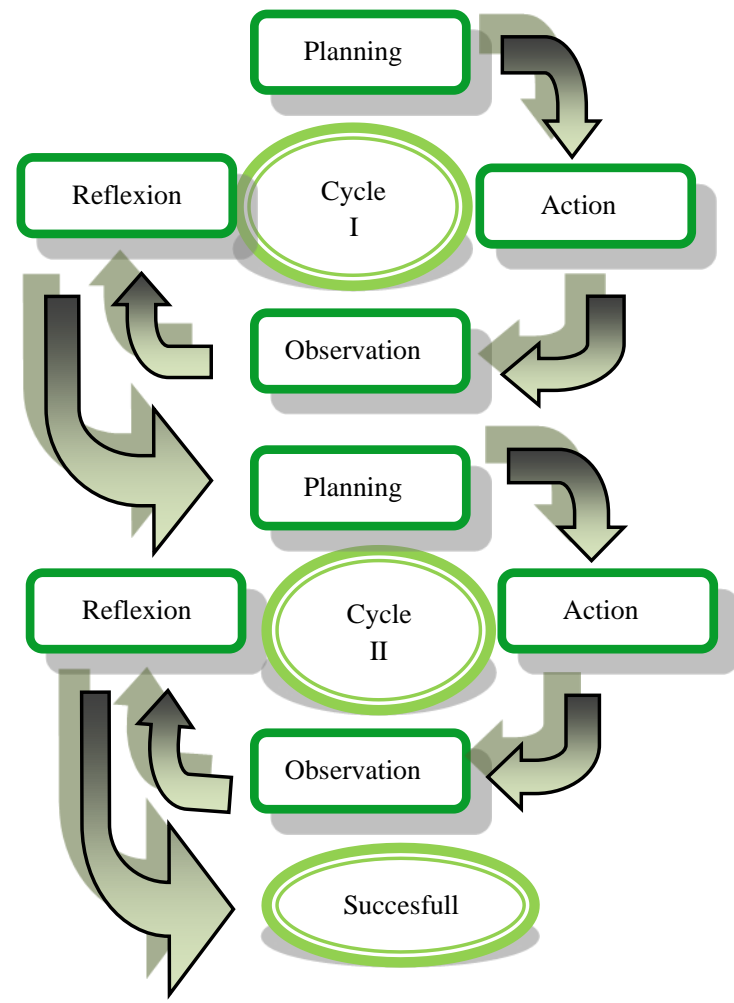

Based on the picture of the research cycle, this classroom action research was conducted in the even semester of the 2012/2013 academic year, which was divided into two cycles, with the following details:

1. Cycle I was held for 2 meetings. Cycle I lasted for 2 meetings. Based on the action research procedure, the activities carried out in the first cycle stage were presenting teaching materials, carrying out learning activities by implementing group investigation type cooperative learning, and carrying out evaluations of the material that had been given for the first cycle.

2. Cycle II was carried out for 2 meetings. The implementation of the actions taken in the second cycle is an improvement and refinement of the performance of the activities in the first cycle. Therefore, the plans and actions in the second cycle are prepared after implementing the steps in the first cycle is completed.

3. Observation (Observation). At this stage, observing and recording students during the teaching and learning process takes place. The recording is done by filling in the observation sheet during the teaching and learning process.

Data collection techniques according to (Pratami et al., 2019) used in this study are:

1. Test. The test is carried out in the form of group work (group investigation type model) to measure students' abilities and understanding of the material being studied so that with group work, student learning outcomes can be known to increase or not.

2. Observation. Observation is a way of collecting data by recording the activities carried out by students and teachers during the teaching and learning process to determine the suitability between planning and implementing actions. Researchers use the observation sheet as a guide when 
carrying out observations for accurate data in observations during the learning process.

3. Documentation. This technique is carried out during teaching and learning activities in the form of photos of student activities during group work in the learning process.

The data analysis used is descriptive qualitative, answering and solving problems by understanding and deepening thoroughly and entirely from the object under study to obtain descriptive conclusions according to the conditions and time. The data obtained through observation were analysed qualitatively (Richardo, 2015). While the learning outcomes obtained by students were analysed quantitatively and then described systematically so that a conclusion can be obtained.As for the relationship with relevant research (Nur Akly, 2015) that the research instruments used were observation sheets, Student Worksheets (LKS) and Group Attendance Lists.

\section{DISCUSSION}

This chapter discusses the results of research that has increased learning outcomes, student learning activities, and teacher teaching activities after the Civics learning process using a group investigation type learning model (Group Investigation) in class X.3 students of State Senior High School Makassar. The subjects of this study were 39 students of class X.3.
ISSN: p-2540-8763 / e-2615-4374

DOI: $10.26618 /$ jed.v\%vi\%i.6521

Vol: 7 Number 1, January 2022

Page: 52-62

Based on the initial observations, several weaknesses were found in the learning process. This weakness can be seen as a problem in learning. These problems, apart from the teacher, also come from the students. Based on observations, the problems experienced by teachers are in terms of poor teaching preparation, such as lack of understanding of student conditions, the application of unattractive learning models, and while learning, the teacher is monotonous so that interactive learning is not created. (Bate'e Award, 2015).

The problem faced by students in class X.3 learning Civics is the lack of students' ability to work on group assignments. To overcome these problems, researchers practiced with partner teachers to find solutions to overcome learning difficulties experienced by students. The key is to apply a model that can improve student learning outcomes using the group investigation type learning model (Group Investigation) during Civic Education learning in the classroom. (Richardo, 2015).

After obtaining data from preobservation results and information from partner teachers that class X.3 is a class that has problems in terms of lack of ability to do group assignments, it is then determined that Classroom Action Research (CAR) or Classroom Action Research will be assigned to class X.3. 
This stage is the main research activity, namely the implementation of a previously planned lesson plan. The learning that can be applied uses a group investigation type learning model (Group Investigation) on the material Analysing the basic relationship of the state with the constitution.

Researchers carried out observation activities in the implementation of group investigation type learning (Group Investigation). In implementing the group investigation type learning model (Group Investigation), the researcher observes student activities during the learning process and monitors the teacher's activities in the group type learning model (Group Investigation). (Ayuwanti, 2016)

These activities are carried out using observation guidelines or observation sheets researchers have made. This observation is significant to see whether or not there is an increase in student learning outcomes in doing group assignments in Citizenship Education learning through a group investigation type learning model (Group Investigation).

The reflection stage is carried out on the results of observations or observations that have been made on the course of the Citizenship Education Learning process (PKn) with a group investigation type learning model (Group Investigation). In this reflection stage, the observations are collected and then analyzed (Lestari \& Cahyono, 2019).
The results of the analysis and reflection of action I are expected to improve action II. Action II was carried out on Tuesday. During the same lesson hours, 09.00 - 10.30 WITA. Thirty-nine students take part in the learning process.

The second learning action (last cycle) was carried out in two meetings. In action II, the teacher starts the learning process by saying greetings, checking the readiness of students and the cleanliness of the class and learning tools, asking for news, checking student attendance by mentioning the names of students one by one.

Then proceed with evaluating the learning process in the previous week and informing the material to be discussed, namely "Analyzing the substance of the state constitution." (Rosmaya, n.d.).

At this stage, observations or observations on the implementation of learning are carried out by applying a group investigation type learning model (Group Investigation) that uses observation guidelines or observation sheets that researchers have made. Learning with the group investigation method begins with group division. Furthermore, the teacher and students choose certain topics with problems that can be developed from those topics. After the topic and its problems are agreed upon, students and teachers determine the research method developed to solve the problem. This observation is very important to see if any 
changes occur in the second learning cycle with the group investigation type learning model (Group Investigation).

Similar to the implementation in the first cycle, in the second cycle, reflection was also carried out on the results of observations or observations that had been made on the course of learning by applying group investigation type learning (Group Investigation). In this reflection, the results of observations are collected, and student evaluations are also analysed.

The observations and initial ability data show that the number of students whose scores reach the KKM is 36 people. This indicates that the Civics ability of students in class X.3 is still low. Based on this, a group investigation type learning model (Group Investigation) was applied as a solution to the problems faced by students in class X.3. Cycle I was carried out for 2 meetings. At the end of the first cycle, a test of learning outcomes was held to present several basic sub-topics of the State and the completed constitution. The descriptive analysis of the Civics learning outcomes of students after the action was taken in the first cycle was the highest score of 80 and the lowest score of 13 , which means that the Civics learning outcomes that students can achieve are spread from the lowest score of 13 to 80 .

Cycle II was carried out for 2 meetings. During the second cycle, a group investigation type learning model was applied
(Group Investigation), but several changes were made based on the reflection results in the first cycle. A learning outcome test was held at the end of the second cycle. Descriptive analysis of student Civics learning outcomes after the action in the second cycle was the highest score of 94 and the lowest score of 65 . Overall, from the results of the analysis of the final results of the first cycle and second cycle, it was obtained that:

1. The number of students in the first cycle who obtained a complete score of 24 people indicates that the learning outcomes in the first cycle have decreased compared to the number of students in the initial ability data.

2. The number of students in the second cycle who obtained a complete score of 39 people indicates that the learning outcomes in the second cycle have increased compared to the number of students in the initial ability data.

\begin{tabular}{|c|c|c|c|}
\hline No. & $\begin{array}{c}\text { Students' } \\
\text { Name }\end{array}$ & $\begin{array}{c}\text { Score of } \\
\text { cycle 1 }\end{array}$ & $\begin{array}{c}\text { Scoreof } \\
\text { cycle 2 }\end{array}$ \\
\hline 1. & MI & 73 & 85 \\
\hline 2. & FL & 74 & 89 \\
\hline 3. & ANP & 60 & 80 \\
\hline 4. & NH & 73 & 75 \\
\hline 5. & RA & 13 & 65 \\
\hline 6. & DAS & 62 & 89 \\
\hline 7. & HI & 74 & 89 \\
\hline 8. & NA & 65 & 66 \\
\hline 9. & SW & 73 & 75 \\
\hline 10. & SM & 80 & 94 \\
\hline 11. & ML & 72 & 89 \\
\hline 12. & MD & 73 & 86 \\
\hline 13. & FM & 60 & 89 \\
\hline 14. & RI & 68 & 84 \\
\hline 15. & NA & 73 & 87 \\
\hline 16. & SH & 68 & 77 \\
\hline
\end{tabular}




\begin{tabular}{|c|c|c|c|}
\hline 17. & PI & 73 & 75 \\
\hline 18. & SRS & 65 & 70 \\
\hline 19. & KS & 70 & 75 \\
\hline 20. & AYS & 71 & 89 \\
\hline 21. & EPS & 60 & 65 \\
\hline 22. & MTR & 78 & 92 \\
\hline 23. & AAL & 78 & 88 \\
\hline 24. & MM & 63 & 82 \\
\hline 25. & SNS & 60 & 86 \\
\hline 26. & MTR & 55 & 74 \\
\hline 27. & RA & 74 & 85 \\
\hline 28. & AJ & 65 & 74 \\
\hline 29. & MA & 72 & 75 \\
\hline 30. & AA & 73 & 75 \\
\hline 31. & FS & 14 & 85 \\
\hline 32. & ISL & 65 & 72 \\
\hline 33. & AR & 66 & 89 \\
\hline 34. & ABAF & 74 & 86 \\
\hline 35. & LRTA & 65 & 89 \\
\hline 36. & FKR & 67 & 82 \\
\hline 37. & SI & 65 & 88 \\
\hline 38. & TA & 66 & 72 \\
\hline 39. & WR & 73 & 86 \\
\hline
\end{tabular}

Besides the increase in Civics learning outcomes during the research from cycle I to cycle II in the table above, several changes occurred in students.

As for the relationship with relevant research (Azmi Purnamasari, Ulul, 2018) regarding these changes obtained from the observation sheet at each meeting recorded by the observer during the study. The changes referred to are as follows:

1. The interaction of students with teachers in each cycle increases. It can be seen from the increase in the number of students who pay attention to the teacher's explanation. This increase is due to the fact that students are more challenged to understand the primary material of the State and the constitution and the substance of the State constitution being taught. By understanding the material, they can more efficiently solve the problems given to give the best results for the group.

2. The number of students who are active during group work increases. Although the increase was not too significant, this increase showed that student activity was better.

3. The number of students who expressed their opinions based on group work results increased. This increase occurs because, during the learning process, students are always conditioned to an atmosphere where students can show their courage.

4. The number of students responsible for doing group assignments increases. This shows that students' confidence and selfconfidence have begun to increase.

5. The ability of students to work together increases, as seen from the number of active students during group work.

\section{CONCLUSION}

Based on the results of the research and discussion above, it is concluded that:

1. The application of the cooperative learning model with the type of group investigation (Group Investigation) on the essential competencies of the basic relationship between the state and the constitution and the substance of the state constitution can improve learning outcomes (cognitive) for 
class X.3 students of State senior high school and have achieved a score of 94 and declared complete.

2. Civics learning by using a cooperative learning model of group investigation type (Group Investigation) can improve student learning outcomes. This can be seen from student learning activities which increased in the first cycle with the qualifications changing enough to be good in the second cycle. In addition, the teaching activities of teachers have also increased. In the first cycle, the qualifications changed enough to be good in the second cycle.

3. The use of cooperative learning model of group investigation type (Group Investigation) in Civics learning can improve student learning outcomes (Cognitive) in Class X.3 State senior high school Makassar which can be seen from student Civics learning outcomes, namely from the moderate category in the first cycle it increased to a category high in cycle II.

\section{REFERENCES}

[1] Akbal, M. (2016). Pendidikan Kewarganegaraan dalam Pembangunan Karakter Bangsa. Gadjah Mada University Press Bekerjasama Dengan LAN RI., 1(1), 485-493.

[2] Anugerah Bate'e. (2015). Penerapan Model Pembelajaran Kooperatif Tipe Group Investigation Untuk Meningkatkan Motivasi Dan Hasil Belajar Matematika Sd Negeri 4 Idanogawo. Jurnal Bina Gogik, 2(1), 25-37.

[3] Ayuwanti, I. (2016). Meningkatkan Aktivitas dan Hasil Belajar Matematika Menggunakan
Model Pembelajaran Kooperatif Tipe Group Investigation di SMK Tuma'ninah Yasin Metro. SAP (Susunan Artikel Pendidikan), l(2), 105-114. https://doi.org/10.30998/sap.v1i2.1017

[4] Azmi Purnamasari, Ulul, D. (2018). MENINGKATKAN AKTIVITAS BELAJAR SISWA PADA MATA PELAJARAN IPA DENGAN MODEL PEMBELAJARAN KOOPERATIF TIPE GROUP INVESTIGATION. Berkala Ilmiah Pendidikan Fisika, 6(1), 130-141. http://dx.doi.org/10.1016/j.neuropsychologia. 2015.07.010\%0Ahttp://dx.doi.org/10.1016/j.v isres.2014.07.001\%0Ahttps://doi.org/10.1016/ j.humov.2018.08.006\%0Ahttp://www.ncbi.nl m.nih.gov/pubmed/24582474\%0Ahttps://doi. org/10.1016/j.gaitpost.2018.12.007\%0Ahttps:

[5] Cahyani, Y., Rasyid, M. R., Nur, F., \& Sulasteri, S. (2019). Efektivitas Media Blok Pecahan dan Media Power Point Terhadap Tingkat Pemahaman Konsep Operasi Pecahan Siswa. Alauddin Journal of Mathematics Education, 1(2), 108-113.

[6] Hamdani, D. (2010). Penerapan Model Pembelajaran Kooperatif Tipe Investigasi Kelompok Dengan Media Software Microsoft Power Point Untuk Meningkatkan Hasil Belajar Siswa Di Kelas Xi Ipa I Man Model Kota Bengkulu. Jurnal Exacta, VIII(2), 54-63.

[7] Haryati, Y. (2020). Penerapan Model Pembelajaran Kooperatif Tipe Group Investigation Untuk Meningkatkan Aktivitas Dan Hasil Belajar Matematika. Penelitian Pendidikan, 11(2), 177-188. https://doi.org/10.47766/itqan.v11i2.949

[8] Indonesia, P. R. (2003). Undang-undang Republik Indonesia Nomor 20 Tahun 2003 Tentang Sistem Pendidikan Nasional. In Dewan Perwakilan Rakyat Republik Indonesia.

[9] Lestari, E., \& Cahyono, H. (2019). Penerapan model pembelajaran group investigation pada materi lingkaran untuk meningkatkan kemampuan berpikir kritis. Jurnal Math Educator Nusantara (JMEN), 5(2), 124-139. https://doi.org/10.29407/jmen.v5i2.12814

[10] Nur Akly, A. H. (2015). EFEKTIVITAS PENERAPAN MODEL PEMBELAJARAN KOOPERATIF TIPE GROUP 
INVESTIGATION (GI) TERHADAP HASIL BELAJAR FISIKA. Jurnal Pendidikan Fisika, 3(1), 52-57. $\quad$ http://journal.uinalauddin.ac.id/indeks.php/PendidikanFisika\% $\underline{\text { OAISSN }}$

[11] Pratami, A. Z., Suhartono, S., \& Salimi, M. (2019). Penerapan model pembelajaran group investigation untuk meningkatkan hasil belajar Ilmu Pengetahuan Sosial. Harmoni Sosial: Jurnal Pendidikan IPS, 6(2), 164-174. https://doi.org/10.21831/hsjpi.v6i2.23535

[12] Ratnaya, I. G. (2013). Implementasi Pembelajaran Kooperatif Tipe Group Investigation Untuk Meningkatkan Aktivitas Dan Hasil Belajar Matematika. Jurnal Pendidikan Dan Pengajaran, 46(2), 125-135.

[13] Richardo, R. (2015). Eksperimentasi Model Pembelajaran Kooperatif Tipe Investigasi Kelompok (Group Investigation) Terhadap Hasil Belajar Matematika Berdasarkan Gaya Belajar Siswa. Edu Research, 4(1), 35-42. https://e-

journal.upp.ac.id/index.php/EDU/article/view $\underline{1413}$

[14] Rosmaya, E. (n.d.). Pembelajaran Menulis Teks Eksposisi dengan Menggunakan Pendekatan Kooperatif Tipe Investigasi Kelompok di SMP. Deiksis: Jurnal Pendidikan Bahasa Dan Sastra Indonesia, 111-127.

https://doi.org/10.33603/deiksis.v5i1.999

[15] Tien, Woro, D. (2018). Perbandingan Hasil Belajar Dengan Model Pembelajaran mandiri dan Kooperatif Tipe Investigasi Kelompok Pada Sistem Reproduksi. Jurnal EduSains, 6(2), 54-60.

https://doi.org/10.36985/jpbm.v8i2.390 